\title{
Pridoli (Silurian) Graptolites in association with Baragwanathia (Lycophytina)
}

\author{
M. J. GARRATT \& R. B. RICKARDS
}

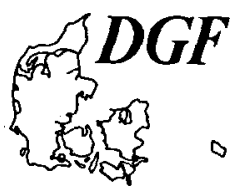

Garratt, M. J. \& Rickards, R. B.: Pridoli (Silurian) graptolites in association with Baragwanathia (Lycophytina). Bull. geol. Soc. Denmark, vol 35, pp. 135-139. Copenhagen, July 1st, 1987.

https://doi.org/10.37570/bgsd-1986-35-14

\begin{abstract}
A locality at Ghin Ghin (Yea, Victoria, Australia) has yielded Monograptus cf. prognatus Koren' from strata demonstrably lying between Ludlow (Silurian) and Devonian rocks, containing floras which include Baragwanathia in association with graptolites.
\end{abstract}

M. J. Garratt, PO Box 173, East Melbourne, 3002, Victoria, Australia. R. B. Rickards, Sedgwick Museum, Department of Earth Sciences, Downing Street, Cambridge CB2 3EQ, England, October 21st, 1986.

\section{Introduction}

The debate surrounding the occurrences of the earliest Baragwanathia floras has been summarized by Garratt and Rickards (1984) and Garratt et al. (1984). Garratt has recently collected numerous graptolites, which form the subject of this paper. The locality is at the previously recorded site of Ghin Ghin; although stratigraphical and geographical details were given in the above papers, we have included in text figure 1 a precis of the section and an up-to-date summary of the finds. The new locality, B2, occurs stratigraphically between beds which we have previously shown to be of Ludlow age (B3: locality 1 of Garratt \& Rickards, 1983) and beds above the $\mathrm{Hu}$ mevale Formation which have long been known to yield undoubted Baragwanathia floras in association with Devonian graptolites. The new (B2) locality has abundant specimens which we have identified as Monograptus cf. prognatus Koren' a species typical of Pridoli strata (Koren' 1983). It seems likely, therefore, that this level of the $\mathrm{Hu}$ mevale Formation, roughly just above the Rice's Hill Sandstone Member exposed elsewhere, is of Pridoli (Silurian) age and is underlain by Ludlow (B3) and overlain by Devonian (such as the Baragwanathia (upper) plant assemblages close to the Flowerdale Sandstone Member).

It will be noticed on the Ghin Ghin section log (text fig. 1) that two further graptolite horizons have been recorded (localities B4 and B1A). This material was only discovered as the present work was completed for press and only preliminary results are to hand on quite large collections. The material, however, does seem to support the contention of this paper that this part of the Humevale Formation is of Pridoli age. The graptolites of $\mathrm{B} 4$ are once again in close association with Baragwanathia floras.

Thus the Pridoli plant graptolite associations established bridge the stratigraphical gap between earlier (Ludlow) and later (Devonian) Baragwanathia/graptolite associations.

Finally we should mention another possible Pridoli graptolite, Monograptus cf. mironovi Koren' from the Humevale Formation at Mooroolbark. In contrast to the above-mentioned localities we have here a single specimen, hence its correlative value is proportionately decreased. It is not found in association with plant material.

Systematic Descriptions

Suborder Monograptina Lapworth, 1880

Family Monograptidae Lapworth, 1873

Genus Monograptus Geinitz, 1852

Monograptus cf. prognatus Koren'

?1969 Monograptus aff. angustidens Přibyl; Jackson \& Lenz, p. 21, pl. 3, figs 6-9, pl. 5, fig. 7

1975 Monograptus angustidens Přibyl; Mikhajlova (pars), p. 154, pl. 37, figs 23

1976 Monograptus angustidens Přibyl; Mikhajlova, pl. 1, fig. 21 


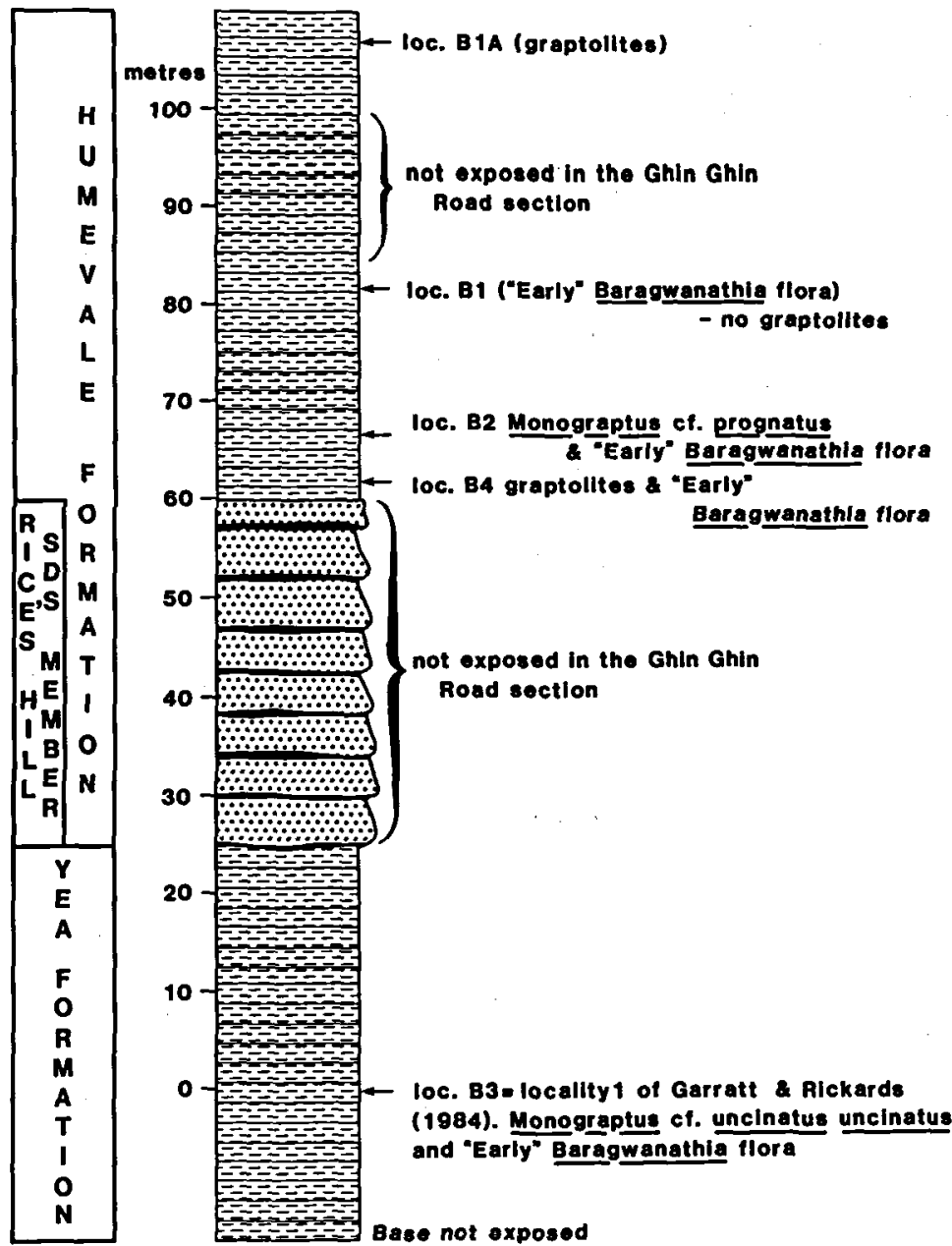

Text figure 1. Stratigraphic log of Ghin Ghin section. Dashed ornament represents siltstone; black lines, claystone intervals; stipple, sandstones (all diagrammatic). Near Yea, Victoria, Australia.

?1978 Monograptus aff. angustidens Přibyl; Jackson, Lenz and Pedder, p. 21, pl. 3, fig. 4

1983 Monograptus prognatus sp. nov.; Koren', pp. 424,427 , pl. 51, figs 8-14, pl. 52, figs $1-5$, text fig. 6

Material and locality. About 70 specimens from locality B2 (text fig. 1) at Ghin Ghin, near Yea, Victoria, $67 \mathrm{~m}$ stratigraphically above the Ludlow locality described in detail by Garratt \& Rickards (1984). All specimens deposited in the National Museum of Victoria collections.

Description. The rhabdosomes are up to $35 \mathrm{~mm}$ long, more or less straight, but with a characteristic gentle dorsal curvature at the proximal end involving th3-th6. The maximum dorso-ventral width, including thecal hoods, is $1.5-1.6 \mathrm{~mm}$.
The sicula reaches almost to the level of the hook of the 2, and has a length of $1.3-1.7 \mathrm{~mm}$ and an apertural width of $0.2-0.3 \mathrm{~mm}$. There is no trace of apertural flaring and the sicular shape varies from straight to, more commonly, slightly ventrally curved. This curvature, and its conspicuous position on the dorsal side of the stipe gives a very gentle doublure flexure to the proximal end of the colony, the extreme proximal end hinting at overall ventral curvature, th3-th 6 with a slight dorsal curvature. In a few specimens the dorsal curvature is maintained to the proximal end. Most rhabdosomes are parallel-sided after about th15, but some show a very gradual increase in dorsoventral width throughout, whilst some show a slight diminution in width. The overall impression on the slabs is of a long, 
Text figure 2. a, Monograptus mironovi Koren', after Koren' (1983); b, Monograptus cf. mironovi Koren', NMV P73515,

Mooroolbark, Victoria, Humevale Formation, just below Lilydale

Limestone; $c$, Monograptus similis Pribyl, sketch of holotype; d, Monograptus prognatus Koren', after Koren' (1983); e,f, Monograptus cf. prognatus Koren' NMV P73516, locality B2 (text figure 1), Ghin Ghin, Victoria; $\mathrm{g}, \mathrm{h}$, proximal ends of

Monograptus cf. prognatus Koren', NMV P73516, showing detectable though slight deformation; i, Monograptus thomasi Jaeger, after Garratt \& Rickards (1984). All figures approximately $10 ; \times 1 \mathrm{~mm}$ scale bar given with each specimen; arrows indicate direction of slight deformation.

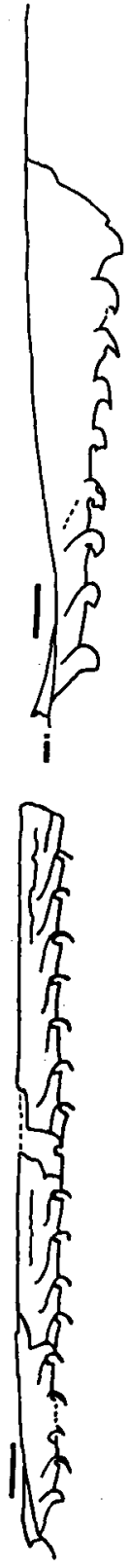

a

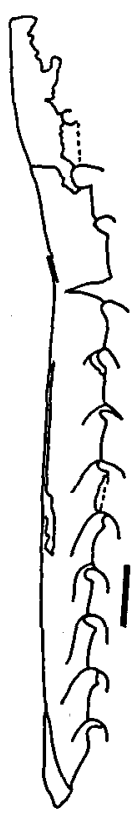

b

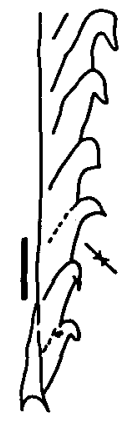

$\mathbf{g}$

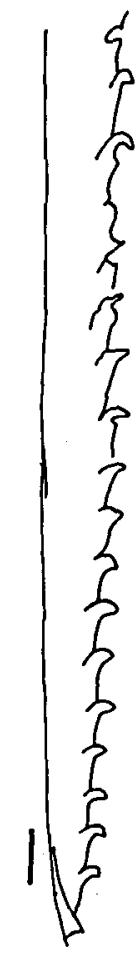

c

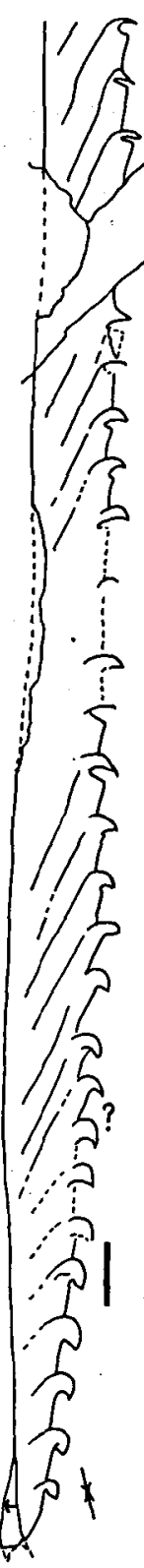

e

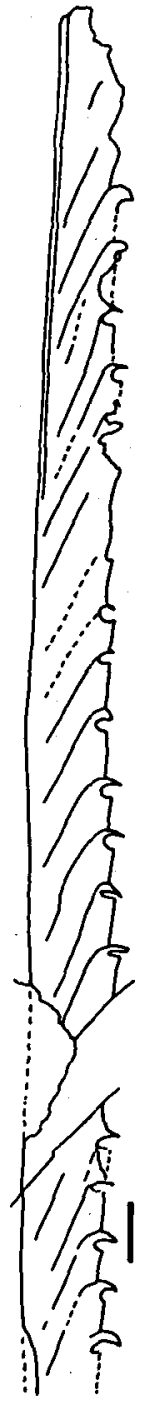

f portion of the dorso-ventral width (1/4-1/5). The height of the thecal hoods is about $0.2 \mathrm{~mm}-0.3$ $\mathrm{mm}$ and the maximum length, in distal thecae, perhaps $0.7 \mathrm{~mm}$.

Thecal length ranges from about $1 \mathrm{~mm}$, more the distal thecae the ventral apertural margin is often visible beneath the hood, even when the latter is very long, but in the proximal thecae the dorsal hood usually overgrows and obscures the ventral apertural margin. When it is seen, however, it is a simple margin with little or no hooklike growth, so that the thecal hook in this species is truly a dorsal hood, uniformly developed along the length of the colony. The thecal hoods project $0.2-0.4 \mathrm{~mm}$ beyond the general ventral edge of the colony and thus occupy only a small pro- 
straight, parallel-sided rhabdosome of average robustness.

The thecae are more or less uniform throughout the rhabdosome, long, overlapping tubes, weakly sigmoidal and with long dorsal hoods. In or less, at the proximal end to more than $3 \mathrm{~mm}$ distally. Thecal overlap is conspicuous and increases from slightly less than $1 / 2$ proximally to $2 / 3$ distally. At th 5 a cross section to the stipe at the level of a thecal aperture might touch the base of one inter thecal septum: at th 20 such a section cuts one interthecal septum and the base of the next one. The lateral width of the distal thecal tubes is around $0.3-0.4 \mathrm{~mm}$ when measured halfway along the thecal length. The angle of thecal inclination is not always very easy to measure because in the preservation of this material the interthecal septum has often become obscured: it seems to be of the order of $20^{\circ}-25^{\circ}$ in the mesial to distal thecae. Thecal spacing varies from 12 in $10 \mathrm{~mm}$ proximally to 9 or 10 in $10 \mathrm{~mm}$ distally.

Remarks. The Ghin Ghin specimens are very close to Koren's species from the Pridoli of the Aksaj Mountains (Koren', 1983). Like that species they have a more or less uniform hood throughout the length of the rhabdosome and in this regard can be distinguished from some later species such as $M$. uniformis angustidens Přibyl, $M$. praehercynicus Jaeger and $M$. thomasi Jaeger. The only real morphological difference between our present material and that described by Koren' is that the Yea specimens may have a slightly higher angle of thecal inclination, though less than in $M$. birchensis Berry for example. Otherwise most of the dimensions closely agree as well as the shape and curvature of the rhabdosome. Further contrast should be made with the not dissimilar species $M$. thomasi Jaeger because that occurs in the nearby Devonian strata (we illustrate a specimen from Eglinton Road Cutting for comparison; text fig. 2i). $M$. thomasi has a very characteristic narrowed, drawn out, proximal end and a resulting strong ventral projection of th1. Other features such as thecal spacing, thecal inclination and thecal overlap are different and the thecal hood in $M$. thomasi declines fairly quickly reaching a minimum at th12-th15 where it is usually little more than a flange about the aperture. An exception in this single respect is Jaeger's
(1966) plate 43 arrowed specimen. Koren' (1983) suggests that a lineage may have existed from $M$. similis Pribyl (holotype illustrated herein for comparison) to $M$. prognatus Koren'. We would support this and add that we suspect that our specimens may be fairly close to the bottom end of the total range of $M$. prognatus; in short, not far removed in time from Pribyl's species. We have no hard and fast evidence for this suggestion, but the extreme proximal end of our form does have similarity to that of $M$. similis. On other counts they differ significantly, especially on thecal overlap.

\section{Monograptus cf. mironovi Koren'}

1975 Monograptus aequabilis Přibyl; Mikhajlova (pars), pl. 38, figs. 1,2

1983 Monograptus mironovi sp. nov.; Koren', pp. 240,423 , pl. 51, figs $1-3$, text fig. 5 a-e.

Material and locality. A single part and counterpart, preserved in low three dimensions from the Department of Mines locality M100 at Mooroolbark at the corner of Williams Road and Turners Road. NMV number P73515 a,b. Humevale Formation.

Remarks. A comparison of text figs $2 a$ and $b$ shows the great similarity between $M$. mironovi Koren' and our specimen. The thecal spacing; size, shape and position of the sicula; thecal type; nature of the apertural hood and thecal aperture; and free ventral wall are all very close. There are two interelated differences: the dorsoventral width is greater in the Australian specimen, even allowing for the very slight difference in magnification, and, in consequence, the angle of inclination of the interthecal septum is slightly higher. However, we cannot yet know the range of variation in the Victorian species. $M$. similis Pribyl is also close to our specimen, but it seems usually to be more robust distally. The Victorian specimen does strongly suggest that it has reached a parallel-sided stage by as early as th5. There can be no doubt about the close relationship of the three forms and it is possible that at Mooroolbark, which can only be low in the Pridoli, that we are close to the divergence of $M . m i-$ ronovi from $M$. similis. 


\section{Dansk sammendrag}

Lokaliteten Ghin Ghin ved Yea, Victoria, Australien har ydet eksemplarer af Monograptus cf. prognatus Koren' fra lag der kan vises at ligge mellem lag af ludiow alder (silur) og devone bjergarter. Lagene indeholder floraer der omfatter Baragwanathia sammen med graptolitterne.

\section{References}

Garratt, M. J. \& Rickards, R. B. 1984. Graptolite biostratigraphy of early plants from Victoria, Australia. Proc. Yorks. Geol. Soc. 44, 377-384.

Garratt, M. J., Tims, J. D., Rickards, R. B., Chambers, T. C. \& Douglas, J. G. 1984. The appearance of Baragwanathia (Lycophytina) in the Silurian. Bot. Jn Linn. Soc. 89, 355-8.
Jackson, D. E. \& Lenz, A. C. 1969. Latest Silurian graptolites from Porcupine River, Yukon Territory. Contr. Can. Palaeontology 182, 17-29.

Jackson, D. E., Lenz, A. C. \& Pedder, A. E. H. 1978. Late Silurian and early Devonian graptolites, brachiopods and coral faunas from North Western and Arctic Canada. Spec. Pap. geol Ass. Can. 17, 1-159.

Jaeger, H. 1966. Two late Monograptus species from Victoria, Australia, and their significance for dating the Baragwanathia flora. Proc. Roy. Soc. Victoria 79, 393-413.

Koren', T. N. 1983. New late Silurian monograptids from Kazakhstan. Palaeontology 26, 407-434.

Mikhajlava, N. F. 1975. Graptolity. In Menner, V. V. (ed.) Kharakteristika fauny pogranichniykh sloev siluria $i$ devona Tsentral' nogo Kazakhstana. Materialy po geologii Tsentral' nogo Kazakhstana 12, 151-158.

Mikhajlova, N. F. 1976. Postudlouskie graptolity Kazakhstana. In Kaljo, D. L. \& Koren', T. N. (eds) Graptology $i$ stratigrafiya. Akad Kauk Estonskoi SSR, Institut Geologii, Tallin, 256 pp. 